\title{
BLACK VS. TARSKI EN EL "PROBLEMA FILOSOFICO DE LA VERDAD"
}

JUAN A. NUÑ̃o

Universidad Central de Venezuela

¿Cuál es el "problema filosófico de la verdad", si acaso existe? Cuando Tarski emprendió la tarea de definir una proposición verdadera en determinados lenguajes, ${ }^{1}$ admitió simultáneamente que el problema en cuestión pertenecía a la teoría del conocimiento, con lo cual se estaba estableciendo, al menos programáticamente, la conexión con la filosofía tradicional. A partir de esa conexión, Black no vacila ${ }^{2}$ en reprocharle a Tarski lo poco o nada que sus resultados ayudaron a "esclarecer el problema filosófico de la verdad".

Conviene determinar el alcance y sentido del reproche de Black, si es que no se quieren confundir dos tesis: de un lado, la posición formalista (característica plenamente de Tarski y, parcialmente, de Carnap), y del otro, la posición "naturalista", bien representada por el propio Black, pero no exclusivamente. La tesis formalista sostiene que sólo tiene sentido hablar de 'verdad' ('falsedad') y de 'proposición verdadera (falsa)' dentro del contexto bien formado de un lenguaje formalizado, que Tarski definía así:

"If in specifying the structure of a language we refer exclusively to the form of the expressions involved, the language is said to be formalized. In such a language theorems are the only sentences which can be asserted."

1 Cf. 'Der Wahrheitshegriff in den formalisierten Sprachen' (Studia Philosophica, 1, 1936). Traducido como: "The concept of truth in formalized languages", en: A. Tarski, Logic, Semantics, Metamathematics, Oxford, 1956. Cf. 'The semantic conception of truth and the foundations of semantics' (Philosophy and Phenomenological Research, 4, 1944).

2 Cf. 'The semantic definition of truth' (Analysis, 8, 4, 1948).

3 Op. cit. en 2 supra, reproducida en Readings in Philosophical Analysis (Feigl-Sellars, edit., New York, 1949), p. 57. 
Pero, por su parte, lo que aquí llamamos tesis "natura. lista" se pregunta por la validez del uso del predicado "verdadero' ('falso') en el contexto del lenguaje corriente o 'natural' y, con referencia explícita a la labor emprendida por Tarski, duda de la posible adaptación de la definición formal de 'verdad' a los lenguajes ordinarios.

Desde el punto de vista lógico de un Tarski, tal aplicación es imposible. Tras de estudiar el lenguaje coloquial, encuentra que en éste:

"not only does the definition of truth seem to be impossible, but even the consistent use of this concept in conformity with the laws of logic."

La principal razón de semejante falla se debe a la inexis. tencia en el lenguaje corriente de niveles de lenguaje (i.e., lenguaje-objeto, metalenguaje) coherentes y bien definidos, artificio que permite evitar el empleo, a un mismo nivel, de las expresiones descriptivas del lenguaje y de los nom. bres de dichas expresiones. Cuando un lenguaje presenta esta característica y utiliza, además, el término 'verdadero' ('falso') con referencia a sus propias expresiones, pasa a ser lo que Tarski denomina un lenguaje "semánticamente cerrado". Un lenguaje de este tipo tiene el grave inconveniente de permitir la formación de antinomias (del tipo 'antinomia del mentiroso') siempre, por supuesto, que aspire a observar, en tanto lenguaje coherente, las leyes de la lógica y, en particular, los principios de no-contradicción y de tercero excluído.

Expresado así, pareciera como si la tarea para quienes reclaman la posibilidad de tratamiento lógico del término 'verdad' en el lenguaje natural, consistiría entonces en papasar de un lenguaje "semánticamente cerrado" a otro "se. mánticamente abierto", esto es, a un lenguaje que, en definitiva, impida la formación de antinomias, gracias a la distinción de niveles de lenguaje para la clasificación y uso de sus expresiones.

4 Op. cit., en I supra. p. 153. 
Tarski no considera, sin embargo, viable el procedimiento. Porque el lenguaje ordinario presenta una carencia tal de estructura formal que ni siquiera tiene sentido hablar en él de 'incoherencia lógica':

"We do not know precisely which expressions are sentences, and we know even to a smaller degree which sentences are to be taken as assertible. Thus the problem of consistency has no exact meaning with respect to this language. We may at best only risk the guess that a language whose structure has been exactly specified and which resembles our everyday language as closely as possible would be inconsistent."

Habría que empezar por probar la condición de incoherencia posible en el lenguaje ordinario para poder establecer luego la posibilidad del tratamiento lógico de los términos 'verdad', 'verdadero' y sus complementarios en dicho lenguaje. No deja de haber una cierta contradicción argumental por parte de Tarski en este punto. Por un lado, en efecto, se sirve del lenguaje ordinario para considerar la formación de antinomias como consecuencia de la no distinción de niveles de lenguaje por proceso canónico de formalización; mas, por otro, niega la posibilidad de determinación de la propiedad de coherencia en ese mismo lenguaje. Si no tiene sentido calificar de 'incoherente' al lenguaje ordinario ¿por qué se parte de las antinomias que en él se producen cuando se aplica el término 'verdadero' a las expresiones de ese mismo lenguaje?

A pesar de semejante dificultad, no deja de ser cierto que tampoco tiene sentido pedirle a Tarski (como hace Black, por ejemplo) la posible adaptación de las tesis formalistas sobre el término 'verdad' al lenguaje corriente. Otra cosa sería intentar resolver el sedicente "problema filosófico de la verdad". Lo cual significa que, si se acepta la separación indicada entre lenguaje 'formalizado' y lenguaje 'no-formalizado' (o lenguaje "semánticamente cerrado"), y si se ads.

5 Op. cit., p. 60. 
cribe, aún hipotéticamente, al segundo conjunto de lenguajes asi distinguidos el "11atural" o cotidiano, entonces el tratamiento lógico de los términos 'verdad' y 'verdadero' no es transferible de la primera a la segunda clase. Expresándolo de otra manera: el metalenguaje utilizado para formar la proposición ' $X$ es verdadero' (siempre que, por su parte, 'verdadero', en tanto predicado, pertenezca al lenguaje-objeto, y ' $\mathrm{X}$ ', en tanto nombre descriptivo de una proposición, pertenezca al nivel superior) ha de ser "más rico" que el lenguaje-objeto, esto es, ha de contener variables de un tipo lógico superior.

De donde se infiere que el llamado "problema filosófico de la verdad" es distinto del "problema lógico de la verdad", resoluble por su parte en lenguajes formalizados, de conformidad con las tesis de Tarski o las de Carnap ${ }^{6}$ o las de McKinsey, ${ }^{\top}$ para citar las más conocidas.

$$
* \quad * \quad *
$$

El mismo Black parece estar de acuerdo en separar en terrenos delimitados el tratamiento lógico del filosófico:

"The technical interest of Tarski's work $(\ldots)$ is independent of its philosophical significance (...). The ques. tion of the adequacy of his work as 'philosophical recons. truction' of the preanalytical notion of truth is quite distinct from that of the value of his contributions to the exact study of formal deductive systems."

Pero, al proceder así, se abre una interrogante acerca de las críticas "naturalistas" a Tarski: ¿por qué exigirle a los resultados formalistas aplicabilidad alguna al dominio de los lenguajes naturales? Así como no tendría ningún sentido hablar de la 'completitud' o 'decidibilidad' del lenguaje

6 Cf. Logical Syntax of Language (London, 1937) y Introduction to Semantics (Cambridge, Mass. 1942).

7 J.C.C. McKinsey: 'A new definition of truth' (Synthese, 7, 1948-49).

8 Op. cit. en 2 supra reproducida en M. Black; Language and Philosophy. Studies in Method. Ithaca, 1949, p. 99. 
castellano, tampoco ha de tenerlo pedir la determinación de un criterio de 'veracidad' para las expresiones lingüísticas ordinarias. Esto es, si se acepta la validez de las tesis formalistas en el conjunto de los sistemas deductivos, no debe pedirse el traspaso de dicha validez a lenguajes no-formalizados. 'Verdad' es un término cuyo uso queda establecido mediante recursos estrictamente lógicos, a partir de lenguajes formalizados previamente. Pretender seguir empleando los términos 'verdad', 'verdadero' (y complementarios) en el lenguaje corriente sólo podría hacerse mediante la postu. lación de una zona de problemas específicos para dichos términos, es decir, mediante la aceptación previa de la existencia del llamado "problema filosófico de la verdad".

Ahora bien, la situación de incomunicación entre la clase formalizada de los lenguajes deductivos y el conjunto noformalizado (ni formalizable, según algunos, como Tarski) de los lenguajes naturales es tal que se establece precisamente a partir de las propias tesis "naturalistas", con todas las consecuencias que de ello se derivan:

"We must either resign ourselves to the transitory and

fluctuating nature of the 'concept' of truth offered or look for some other way to define it." "

Ciertamente que aún quedaría una tercera posibilidad, no contemplada en este caso por Black: tratar de eliminar el término 'verdad' ('verdadero'), bien sea por redundante o por equívoco no reducible, del empleo del lenguaje corriente, si es que se desea evitar en éste las expresiones asignificativas o decididamente antinómicas. Pero, al proceder de esta forma, se estaría aceptando de hecho la principal de las consecuencias de las tesis de Tarski, ${ }^{10}$ a saber: afirmar que una proposición es verdadera equivale lógicamente a afirmar dicha proposición.

Este es el punto en el cual los defensores del análisis filosófico de los lenguajes naturales (con la correspondiente

9 M. Black, loc. cit, n. 19, p. 101.

10 Similar a la tesis de Ayer en su Language, Truth and Logic. 
pretensión de esclarecerlos lógicamente en tanto instrumentos de conocimiento) se rebelan contra las tesis formalistas y su derivado radicalismo nominalista. Para evitar entonces la solución extrema que parece acompañar a la definición semántico-formal de 'verdad', se procede a reclamar una solución específica del "problema filosófico de la verdad".

Ahora bien ¿en qué consistirá dicha solución? Y, sobre todo, ¿a qué se hace referencia con dicho problema?

$$
\text { * * * } *
$$

Tras la expresión "problema filosófico de la verdad" se oculta una tesis sustancialista que puede llegar hasta hipostasiar el término 'verdad'. De esta forma, se habla de la "naturaleza" de la verdad y aún de su "esencia natural" "1 como se hablaba en la química precuantitativa de la "naturaleza" del azufre o del oro, o como se hablaba en la filosofía griega primitiva acerca de la "naturaleza" de las cosas. Si la verdad es una entidad tan caracterizable de suyo que tiene sentido atribuirle propiedades ("esencia", "naturaleza", "raíz"), se abren entonces las puertas que dan acceso al realismo más exagerado.

Es de creer que exactamente esa sea la posición de Black cuando pide "a satisfactory general description of usage" 12 o al exigir "a direct solution". Lo general y lo directo apuntan hacia las esencias. Por supuesto, que quien no considere posible lograr un criterio de conocimiento limitado a la re. lación determinada y particular de cada expresión propo. sicional con su designatum, tratará de invocar la existencia de supuestas entidades superiores que ayuden a establecer un conocimiento no sólo general, sino absoluto:

"The philosophical disputants are concerned about what in general entitles us to say 'It is snowing' or 'London is a city' and so on. In other words, they are searching for a

11 M. Black, loc. cit., p. 104.

12 ibidem. 
general property of the designata of true object-sentences. 'l'o this inquiry, the semantic definition of truth makes no contribution."

Todo el pasaje citado destila platonismo. En efecto: ¿qué diferencia hay entre pedir "un cierto eidos" para alcanzar la definición general de areté y buscar esa "propiedad general de los designata"? La definición semántica establece primero una relación entre cierto tipo de expresiones proposicionales ('de objeto' o factuales) y el hecho o estado de los hechos al que dicha expresión se refiere, para exigir en segundo lugar, que dicha relación lo sea de equivalencia en el caso de que las expresiones estudiadas hayan de ser clasificadas en el conjunto de las verdaderas. Es cierto que la definición semántica así entendida no proporciona, en tal caso, sino un criterio indicativo y limitado al tipo de expresiones proposicionales factuales. Lo contrario sería suponer que existe una disposición general de índole pragmática que "nos capacita" para proferir expresiones tales como 'Está nevando' o 'Londres es una ciudad' o cualquier otra y determinar de antemano la corrección de la expresión respecto del designatum. Ahora bien, semejante desplazamiento hacia el nivel pragmático conlleva siempre el peligro de un subjetivismo interpretativo. Con lo cual, la mezcla se torna muy peligrosa: por un lado, se aspira a una 'propiedad general' que traslada el problema in toto al orden de las entidades abstractas (realismo platónico), mientras que, por otro, se pide una 'disposición general' del usuario de las expresiones que replantea el problema del criterio veritativo al nivel del cogito cartesiano.

Es de temer que, en definitiva, con la expresión "problema filosófico de la verdad" se esté aludiendo, mediante el conocido recurso de la descripción definida, al catálogo histórico de los diversos intentos por lograr una caracterización general y comprehensiva de todas las expresiones que aspiren a establecer una determinada relación cognoscitiva. Mas,

13 Black, loc. cit., p. 105. 
en tal caso, el "problema filosófico de la verdad" se reduciría a la descripción detallada y explícita de cada uno de esos intentos históricos, no siendo totalmente imposible que, por su parte, dichas descripciones den lugar a un auténtico problema general, pero esta vez se trataría del problema relativo al supuesto "problema filosófico de la verdad". Dicho de otro modo: si sucediera que, a través de esa revisión crítica de la historia del llamado "problema de la verdad", se llegase a la conclusión de que se trata de la reiterada postulación de un problema no resoluble por carente de sentido (seudoproblema), sólo sería entonces legítimo mencionar el "problema filosófico de la verdad" para aludir a la carencia de sentido del planteamiento, por una parte, y al hecho mismo de su formulación, por otra.

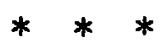

Es impropio, además, hablar de "definición semántica de verdad" para caracterizar el esquema de Tarski que dice:

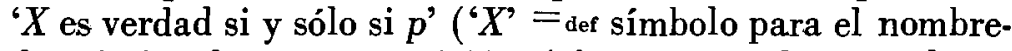
descriptivo de una proposición; ' $p$ ' = ${ }_{\text {def símbolo para desig- }}$ nación de cualquier proposición). Es, en efecto, doblemente impropio: (1) porque, de suyo, esa fórmula no es una definición $^{14}$ y (2) porque su autor nunca la consideró como tal. Los resultados a que llegó Tarski al estudiar el uso de los términos 'verdad' y 'verdadero' en el lenguaje llamado coloquial son enteramente negativos, como se ha resumido supra. Precisamente el esquema ' $X$ es una proposición verdadera si y sólo si $p$ ' es utilizado para poner de manifiesto la imposibilidad de formalizar la semántica del lenguaje natural. A partir del mencionado esquema, se pueden formar paradojas, las cuales sirven para revelar la incoherencia lógica del lenguaje corriente, a consecuencia de introducir en él el empleo de los términos en cuestión. Mal podría entonces

\footnotetext{
14 Como demuestra Black (loc. cit., pp. 92-98) sin demasiado esfuerzo, pues ya lo hizo el propio Tarski.
} 
alcanzar Tarski una 'definición' semántica de verdad con una fórmula que lo que hace es dar origen a dificultades lógicas. Por ello, o vuelve a plantearse el problema a otro nivel (a saber: el propio de los lenguajes formalizados, tales como cálculo de clases o lenguaje finito de primer orden) o queda abierto en el nivel correspondiente al lenguaje ordinario en tanto tal problema, pero entonces con las consecuencias antes señaladas. 
What is the philosophical problem of truth? When Tarski attempted to define a true proposition in certain languages, he thereby admitted that the problem formed part of the theory of knowledge, thus establishing, at least pragmatically, a link with traditional philosophy. On the basis of this link Black points out that Tarski's conclusions were of little or no help in "clarifying the philosophical problem of truth".

Black's criticism should be analysed in order not to confuse two theses: (A) the formalistic position (Tarski and, in part, Carnap) and (B) the naturalistic position, represented by Black, though not exclusively so. The former maintains that one can only speak of 'truth (or falsity)' in formalized language; the latter asks whether the predicate 'true (false)' can be validly used in 'natural' language and doubts whether the formalized definition of 'truth' can be adapted to ordinary languages.

According to Tarski such an application is impossible owing to the fact that in ordinary language there are no coherent and well defined levels (object-language, meta-language) which will allow one to avoid the use on the same level, of expressions descriptive of the language and of the names of such expressions; according to Tarski such a language as uses the term 'true (false)' in reference to its own expressions is a 'semantically closed' language. A language of this type permits of the formation of paradoxes. Thus stated, it would seem that the difficulty of those who wish to handle logically the term 'truth' in natural language would be to pass from a 'semantically closed' language to an 'open' one that, thanks to the distinction of levels, would prevent the formation of par. adoxes.

Tarski rejects this approach. In view of the lack of formal structure in ordinary language there is no sense even in speaking in it of 'logical incoherence'; one would need first to show the conditions of possible incoherence in ordinary language in order afterwards to establish the possibility of dealing with the terms 'truth', 'true' and their opposites. The author points out that in this context Tarski falls into a certain contradiction: on the one hand he uses ordinary language to consider the formation of paradoxes, and on the other he asserts that it is impossible to determine the property of coherence in that same language. If it is senseless to characterize ordinary language as 'incoherent', why should one start out from the 
paradoxes that occur in it when the term 'true' is applied to the expressions of that same language?

All the same it is unreasonable to ask Tarski (as Black does) to adapt the formalistic theses to ordinary language. It would be different if one were trying to solve the so-called "philosophical problem of truth'. Which means that if the difference between formalized and non-formalized language is accepted and if natural language is assigned to the latter class of languages the logical status of the terms 'truth' and 'true' is not transferable from the first class to the second. In other words, the meta-language used in forming the proposition ' $\mathrm{X}$ is true' must be richer than the object-language; it has to include variables of a higher logical type. Hence one may infer that the 'philosophical problem of truth' is different from the 'logical problem of truth'.

Black agrees in separating logical from philosophical treatment. But this introduces a question: Why should one insist that formalistic conclusions should be applied to natural language? If the validity of formalistic theses in deductive systems in general is accepted, one cannot expect this validity to be transferred to nonformalized language: the use of the term 'truth' is established only by strictly logical means. To expect to continue employing the terms 'truth', 'true', etc., in ordinary language is only possible if one postulates an area of specific problems for these terms, that is to say, if one accepts the existence of the 'philosophical problem of truth'.

The 'naturalistic' theses themselves establish this lack of communication between the two kinds of language; Black, for example, observes that we must either resign ourselves to the "transitory and fluctuating nature of the 'concept' truth, or look for some other way of defining it". But there exists a third possibility not envisaged by Black: the elimination of the term 'truth' from ordinary language as redundant and equivocal, thus avoiding the formation of paradoxes. But then this would be equivalent to accepting the principal outcome of Tarski's thesis: to assert that a proposition is true is logically equivalent to asserting that proposition.

What, then, is the philosophical problem of truth? This expression hides a substantialist thesis which might go so far as to hypostatize the term 'truth'. On these lines one might speak of the 'nature' of truth, and even of its 'natural essence'; if truth is an entity to which it is reasonable to attribute properties ('essence', 'nature', 'root') the doors are thrown open to the most exaggerated realism. This seems to be Black's position when he asks for 'a satisfactory general description of usage' or demands 'a direct solution'; 
the words general and direct point towards essences. What difference is there in effect between asking for 'a certain eidos' in order to arrive at a general definition of areté and seeking that 'general property of the designata'?

In the first place the semantic definition establishes a relation between a certain type of expressions (factual) and the fact or state of affairs to which the expression refers; in the second place it requires that this relation should be one of equivalence if the expressions are to be classified in the set of the true ones. Taken in this way, of course, the semantic definition will provide no more than an indicative criterion restricted to the factual propositional type of expressions. Otherwise one would have to assume the existence of a pragmatic kind of general disposition which would 'enable us' to utter expressions such as 'It's snowing' or any other and determine beforehand the correctness of the expression with respect to the designatum. This leads to a very dangerous muddle; on the one hand we look for a 'general property', but this will transfer the problem in toto to the class of abstract entities (Platonic realism) while on the other we ask for a 'general disposition' of the user of the expressions, which brings up again the problem of the criterion of truth on the level of the Cartesian cogito.

It is to be feared that the expression 'philosophical problem of truth' is definetely referring to the historical catalogue of the various attempts to arrive at a general and comprehensive characterization of all the expressions which aim at establishing a certain cognoscitive relation. That is to say, that if as a result of this critical revision of the so-called 'problem of truth' one reached the conclusion that it was a case of the repeated postulation of a problem that was irresolvable because it lacked meaning (pseudo-problem), it would then be permissible to speak of the 'philosophical problem of truth' only in order to refer to the lack of meaning in the problem on the one hand, and to the very fact of its formulation on the other.

Furthermore, it is incorrect to use the expression 'semantic definition of truth' to characterize Tarski's formula to the effect that: ' $X$ is true if and only if $p$ ' (where ' $\mathrm{X}$ ' $=$ def. symbol for the descriptive name of one proposition, and $p=$ def. symbol to designate any proposition.) It is, in fact, doubly unsuitable: (I) because in itself this formula is not a definition, and (2) because its author never regarded it as such. The results that Tarski arrived at in studying the use of the terms 'truth' and 'true' in so-called colloquial language are completely negative, as has been shown supra. As a matter of fact the formula ' $X$ is a true proposition if and 
only if $p$ ' is used to show how impossible it is to formalize the semantics of natural language. It is possible to use this formula to construct paradoxes, which demonstrate the logical incoherence of ordinary language when the terms in question are introduced into it. So Tarski could hardly arrive at a semantic 'definition' of truth by means of a formula that merely gives rise to logical dif. ficulties. For this reason, either the problem must be stated on another level (for instance that suitable for formalized language such as calculus of classes or finite language of the first order) or it must be left open on the level of ordinary language, but then with the consequences already pointed out. 